\title{
The Sustainability of EU Labor Immigration in Terms of Poverty Inequalities and Employment
}

\author{
Eva Ivanová * (D) and Eva Grmanová \\ Faculty of Social and Economic Relations, Alexander Dubček University of Trenčín, 91150 Trenčín, Slovakia; \\ eva.grmanova@tnuni.sk \\ * Correspondence: eva.ivanova@tnuni.sk
}

Citation: Ivanová, E.; Grmanová, E. The Sustainability of EU Labor Immigration in Terms of Poverty Inequalities and Employment. Sustainability 2021, 13, 2265. https://doi.org/10.3390/su13042265

Academic Editor: Adela García-Aracil

Received: 30 December 2020

Accepted: 12 February 2021

Published: 19 February 2021

Publisher's Note: MDPI stays neutral with regard to jurisdictional claims in published maps and institutional affiliations.

Copyright: (c) 2021 by the authors. Licensee MDPI, Basel, Switzerland. This article is an open access article distributed under the terms and conditions of the Creative Commons Attribution (CC BY) license (https:// creativecommons.org/licenses/by/ $4.0 /)$.

\begin{abstract}
The basic feature of developed economies is a high economic growth rate, which creates the preconditions for a high living standard of population based on high incomes from economic activities. Development processes in advanced economies also include changes in demographic development, resulting in population structure changes, as well as labor force structure changes caused by birth rates reduction and life expectancy increase and an aging process. Due to the high standard of living in European developed countries, they are becoming attractive to less developed countries, having a surplus of labor that migrates to work with a vision of increasing living standards and quality of life. The workforce does not always find full employment here in terms of qualifications, leading to social inequalities between the domestic population and immigrants for whom the social situation poses a risk of poverty. The goal of the article is to determine the specifics of inequalities between the domestic and immigrant population in terms of social status in individual EU countries. Immigrants coming out of the EU are significantly at higher risk of poverty. In most EU countries, the employment rate in the group "nationals" is lower than in the group "foreign" from the EU.
\end{abstract}

Keywords: immigration; labor immigration; poverty risk; employment; social inequality

\section{Introduction}

The current international division of labor development level increases the intensity of international trade in goods and the interconnection of world economies, accompanied by the emergence and development of international financial markets. Common goals and interests link states into integration groups. These trends are highlighted by globalization processes, being accompanied by a high degree of technological progress, electronization and digitization of economic activities in all economically developed countries in European Union, which increases the effectiveness of their economic relations.

One of the four freedoms which exists within the European Union, is the free movement of workers. This includes the rights of movement and residence for workers, the rights of entry and residence for family members, and the right to work in another Member State and be treated on an equal footing with nationals of that Member State.

Freedom of movement for workers has been one of the founding principles of the EU since its inception. It is laid down in Article 45 of the TF EU and is a fundamental right of workers, complementing the free movement of goods, capital and services within the European single market [1].

Demographic development in developed countries also contributes to it, including the population structure changes. In particular, the age population structure is a subject to change. The birth rate reduction and life expectancy prolongation processes are resulting in the population aging process in developed countries. According Grmanová et al. (2018) as a result of aging population, the workforce structure is also to be changed. The workforce is aging and despite the extension of retirement its lack is starting to be visible in many professions or regions within individual states or integration [2]. This fact may affect the 
economic outputs of states. For this reason, the internal and external labor migration is currently being an issue, and thus world regions or states are faced with the issue of immigration.

There can be no doubt that Europe's population is getting older, at least if age is defined in the conventional way, the proportion of the population that is above the age of 65 still widely considered a critical indicator. At the level of the EU-28, this proportion is projected to increase from currently $18.2 \%$ to around $30 \%$ by 2050 , which has given rise to widespread fears about negative economic and fiscal consequences of this demographic trend. As a consequence, either increased immigration or alternatively efforts to increase fertility have been suggested. These issues are also the object of migration policy in the recipient countries [3].

As claims Harper (2016). It is not just technology and globalisation, however, which has encouraged the advanced economies to attract and facilitate the immigration of skilled overseas workers. It is also the age-structural change which is forcing governments to consider migration as a solution to the demographic deficit and population decline. Research shows that the net contribution of migrants is nearly always positive, important given that the major challenge facing the ageing high income counties is one of growing skills shortages [4]. Modern economic growth theory suggests that the interaction of technological progress and capital accumulation is the ultimate source of long-term economic growth. Whether immigration flows cause changes in labor productivity through investments in capital and research and development (R\&D) is an important issue for policymakers. High-skilled immigrants with science, engineering, and other professional skills may contribute to technological improvements in the host countries [5].

Czaika and Reinprecht (2020) defined the dimensionality of migration drivers refers to the nine societal areas a migration driver may be situated in, each comprising of a number of driving factors further specifying these broadly defined dimensions. They are, for example: demographic drivers, economic drivers, socio-cultural drivers, human development drivers, politico - institutional drivers and others [6]. Migration is always the result of a complex combination of macro-, meso- and micro- factors, the former acting at the society level and the latter acting at the family or even individual level. Host countries, which may have also an economic benefit from migration in the medium long-term, have to be prepared to receive migrants for the benefit of the migrants themselves and their native population [7].

According to Eugster (2018) it is not only immigration and the incorporation of immigrants into society that serve as challenges for industrialised and post-industrialised countries, but also rising inequality and poverty. The author further claims that social rightshere understood as their access to paid employment and welfare benefits-condition the impact on society [8].

Haas et al., (2019) claim that there is regulation of migration. Contemporary migration regimes are about selection rather than numbers. Migration policies involve sophisticated sets of policy instruments that simultaneously encourage and discourage the migration of particular groups. Most migration occurs between middle-income and high-income societies and most migrants from low-income countries belong to middle-income groups. Absolute poverty is associated with lower emigration levels, as resource constraints deprive people of the capability to emigrate [9].

The authors Anderson and Huang (2019) also included the duration of labor migration period into migration analysis, they state that the relatively larger increase of migrants is within 5 years of the duration of labor migration, after five years the development is stable or only slightly increasing [10]. The issue of the duration of labor migration is also related to the integration of immigrants into the population in the host country, which is influenced by many factors, but also by the migration policy content in a particular country [11].

In the EU, the population aging process has not started to be evident in all countries at once, and its intensity has varied. States that have struggled with the aging process in 
the past have also taken more promising measures. They formulated a migration policy being aimed at thoughtfully recruiting labor from abroad.

EU countries differ in their economic growth rates, which means that their attractiveness for immigrants also varies. The high standard of living and the high level of wages in host country are important factors for immigrants to decide to leave their home country. At the same time, low living standards and low wages motivate migrants to leave their home country [12].

In general, we can say that, currently any national economy in the EU could not function without internal and external migration. In many areas, there is a labor shortage, which can only be solved by immigration. Thus, economic growth in many EU countries is dependent on labor immigration. Just as international trade and business are issues in word economy now and, in the future, so is the external labor immigration. The need for labor immigration is a long-term issue due to current demographic trends and beneficial.

An opinion can often be met that immigrants cost more than they yield, but rarely relies on empirical evidence. In fact, most existing studies show that the economic effects of immigration in the countries of destination, though limited, are usually positive [13].

The EU can achieve both productivity growth and the increase in employment rates without compromising its social dimension. The existing trade-off between macroeconomic efficiency and long-term sustainability of national welfare systems can be avoided by the modernized European Social Model [14].

If immigrants do not find full-fledged employment within the labor market or are unable to integrate into society despite legislative rules, the absence of income results in their falling into poverty creating a social differentiation in a host country and preconditions for poverty rate increase.

The poverty rate is the proportion of the population which earns less than 60 per cent of median income; since this is a measure of relative rather than absolute poverty, it is also referred to as the at-risk-of-poverty rate. Almost 142 million Europeans are at risk of poverty. The author further states: Official EU statistics mask the alarming extent of poverty and inequality in Europe. National poverty rates in the EU vary between over 25 per cent in Romania and less than 10 per cent in the Czech Republic. For Germany, the figure is 16.5 per cent (2016). The official Eurostat figure for the EU as a whole is 17.3 per cent, which puts poverty in the EU only slightly higher than the level in Germany [15].

Economists have long believed that economic growth alone would suffice to resolve the problems of inequality and poverty [16]. Furthermore Lyubimov [16] highlights Pikety's words in his work Capital and Ideology, where he argues that the higher the economic growth, the bigger the social inequalities [17].

The social inequality problems in European states are becoming more and more significant. This issue has not been solved in the long run, because states, even developed countries have not implemented a systematic migration policy or it has not been set up effectively. A good example could be to attract a highly skilled workforce, specialists in certain fields and occupations, (brain drain). This characterizes, for example, the Czech Republic, where there are many highly qualified forces from Slovakia. The overall situation in the Czech labour market is much better than in the Slovak Republic, also the differences among regions are smaller in CR [18].

If the EU had stagnated and started to see its highly educated citizens leaving-on the scale already observed in some southern and eastern EU countries-it would have been found with a smaller and less educated workforce. Such changes would coincide with a more rapidly ageing population due to the fact that emigrants tend to be early-career adults [19].

With a wrong migration policy setup and with unsystematic institutional reforms, inequalities between immigrants and domestic population can be increased and lead to further inequalities and increase in the poverty rate. If there is no social convergence between the two groups and immigrants do not have a job within the labor market, they burden the social system and their standard of living declines. Rising inequalities can then 
cause uncertainty and jeopardize the sustainability and efficiency of labor immigration process [20].

In our opinion, this was caused mainly due to the growing values of the at-risk-ofpoverty rate in countries where many refugees came from third countries in the short term.

\section{Goal, Data and Methodology}

We consider the reduction of inequalities between domestic population and immigrants to be an important element regarding the sustainability of labor immigration process. The declining development of inequalities between those two groups can be seen as a reflection of a well-designed migration policy. On the contrary, increasing inequalities between those two groups may jeopardize the sustainability of an effective solution within the labor shortage supply with immigrating labor from abroad. For this reason, in our article we will focus on the specification of inequalities between domestic population and immigrants in the countries of EU. We will look at the external immigration issue primarily from the perspective of the recipient country.

From the recipient country's point of view, immigration is beneficial for labor market needs, especially when people immigrate with exceptional job skills or occupations in which the recipient country does not have enough specialists. In the long run, it is beneficial process for the recipient country, even though the labor shortage can be solved by immigration due to the population aging.

According to the European Commission (2011) the year 2010 was declared as the European Year for Combating Poverty and Social Exclusion [21]. A set of tools has been agreed to overcome poverty or social exclusion for the next 10 years. The period since 2010 is also a period when the number of immigrants from third countries has increased significantly. In 2011, a military conflict began in Syria and many refugees were heading for the EU. Gradually, other migration flows from third countries to the EU were emerging. In the years of 2014-2016, the inflow of migrants into the EU was the most extensive. The period since 2010 is therefore the period in which the EU has dealt with migration policy most intensively, mainly due to the large inflow of migrants into the EU.

We assume that the EU's efforts under the Platform Combating Poverty and Social Exclusion are successful and that poverty is being reduced and employment is growing and that these trends are the same for both the domestic population and immigrants. However, at the same time, we assume that differences between the groups of domestic residents and immigrants persist.

There are several reasons for this. Immigrants often work in jobs for a wage that domestic residents are not willing to work for. Domestic residents have already established their social contacts and know the environment in which they work. It takes immigrants some time to make social contacts. Thus, the length of time when immigrants stay in a foreign country is important when it comes to their social status [10].

The country of origin of immigrants is another important factor. Immigrants from third countries have a worse position on labor market and at the same time they have bigger problems with integration into society.

On the other hand, labor shortage leads the EU countries to take measures to attract a suitable workforce through immigration. Upon this it can be assumed that not only is the risk of immigrant poverty reduced, but also the differences between the domestic population and immigrants are reduced. Due to labor market needs and labor shortages, the gap between the domestic population and immigrants is narrowing.

Thus, the push and pull factors described in several professional articles highlight why migrants leave their home country and why they choose their destination country. On the other hand, there are many factors that affect their position in the target country. These include, in addition to migration policy, many other factors. For example, the large networks of immigrants in a destination country that make their situation easier in the first years after immigration [22] and "culture of migration" and others [6]. 
Social security is another important factor. According to Giulietti (2014), in many countries, immigrants, despite higher poverty rate, have less intensive access to social programs than domestic residents [23].

Generous social security is attractive particularly for highly educated migrants [24].

However, in our study we want to point out to an important current phenomenon, namely that the social status is improving both for the domestic population and for immigrants, but the improvement for immigrants is more significant. It means that the differences between them and the domestic population are decreasing. Labor shortages in particular play an important role in this issue.

The aim of the article is, based on analyzes, to confirm the expected trends in the development of differences between the domestic population and immigrants in the field of social status, to determine the specifics of inequalities between the domestic and immigrant population in terms of their social status in the EU and individual EU countries.

We assume that if inequalities in social status between the domestic population and immigrants do not increase, then migration policy is designed in a way that labor immigration is sustainable. At the same time, labor immigration is effective and beneficial for the recipient country in the long run.

In this article, along with the identification of tendencies regarding inequalities between both groups, we will focus on:

- determining the specifics of individual EU countries,

- the dynamics of change,

- the evaluation of convergence, respectively divergent trends among particular EU countries.

We will identify the development trends in inequalities between domestic and immigrant population groups in the areas of:

- poverty

- employment.

These areas have been chosen because they appear to reflect the social inclusion issue. The risk of poverty refers to the proportion of people who have basic necessities of life at risk and thus also reflects their unfavorable social status. The large difference in the indicator values within the groups of domestic population and immigrant population indicates the significant social inequalities. If the gap within the risk of poverty between domestic population and immigrants gets bigger, it can be concluded that the institutional provision of migration policy and the migration system are not at a sufficient level and probably procedural errors can be found there. If the gap between the domestic population and immigrants does not get bigger and EU countries converge in terms of indicator values differences, then these trends may indicate that immigration policies and a labor-oriented immigration system are effective and sustainable.

An important reflection within the social inclusion of immigrants can be seen in employment development. The application of immigrants within the labor market increases their possibilities of social inclusion in a society. On the contrary, unemployed immigrants can oppress the social system.

Inequalities within the risk of poverty will be monitored on the basis of the indicator "people at risk of poverty or social exclusion by broad group of citizenship (population aged 18 and over)". "At risk-of-poverty are persons with an equivalised disposable income below the risk-of-poverty threshold, which is set at $60 \%$ of the national median equivalised disposable income (after social transfers)" (Eurostat, 2020,1) [25]. We drew the data from Eurostat ([ilc_peps05]) [26].

We observed employment inequalities based on the employment rate indicator (population aged 15-64). The indicator is expressed in \%. The data has been drowned from Eurostat ([lfsa_ergan]) [27].

We observe the inequalities within the two groups according to the country of citizenship. The group of domestic population is represented by the people from a reporting 
country ("nationals"). The group of immigrants is represented by the people from foreign countries ("foreign").

The period under review is represented by the years from the adoption of the European Platform Combating Poverty and Social Exclusion until 2018. It is also a period when the numbers of immigrants from third countries have increased significantly.

The 2019 data was available only for some EU countries. Therefore, it was not appropriate to include published data in the analysis.

Within the inequalities, we focus on the following issues:

1. To determine the specifics of individual EU countries we assess the indicators within the level of analyzed indicators, respectively indicators within the level of their differences. To do this, we use descriptive statistics such as arithmetic mean, median, minimum, maximum, standard deviation and variation coefficient.

2. The dynamics of changes. We evaluate the dynamics of changes by the basic index and the average growth coefficient. The average growth coefficient $\bar{k}$ is expressed by the geometric mean according to equation. According Pacáková et al., (2003, p. 244) [28], when $y_{i}$ indicates the value of indicator in the $i$ th analyzed period for $i=1,2, \ldots, T$, then

$$
\bar{k}=\sqrt[T-1]{k_{2} k_{3} \ldots k_{T}}=\sqrt[T-1]{\frac{y_{2}}{y_{1}} \frac{y_{3}}{y_{2}} \ldots \frac{y_{T}}{y_{T-1}}}=\sqrt[T-1]{\frac{y_{T}}{y_{1}}} .
$$

3. The evaluation of convergence, resp. divergent trends among EU countries.

We observe the development of inequalities over the time by means of the Sigmaconvergence. According Minařík, Borůvková, Vystrčil (2013) is based on the assumption that Sigma-convergence occurs in a certain period of time within the analyzed indicator when the variability of a variable, being measured by the standard deviation, decreases. On the contrary, divergence occurs when the variability of a variable, measured by the standard deviation, increases. As a rule, the standard deviation is expressed from logarithmic data [29]. In our analysis, there will also be negative values of the differences in the indicator. Therefore, we will not do logarithmization.

Sigma-convergence is one of two frequently used concepts of convergence. Second concept is beta convergence. According Monfort (2008, p. 4) "Beta-convergence refers to a process in which poor regions grow faster than rich ones and therefore catch up on them. Sigma-convergence simply refers to a reduction of disparities among regions in time." [30] According Sala-i-Martin (1994, pp. 5-6) [31] "two concepts examine interesting phenomena which are conceptually different: Sigma-convergence studies how the distribution of income evolves over time and beta convergence studies the mobility of income within the same distribution." Monfort (2008, p. 5) emphasizes, that "Beta -is a necessary but not a sufficient condition for Sigma-convergence" [30]. In our research we focus on reduction of disparities among regions in time.

\section{Findings and Discussion}

\subsection{People at Risk of Poverty}

In the following section, we deal with the inequality between the domestic and immigrant populations in the area of poverty risk in EU countries. Table 1 provides descriptive statistics on the indicator people at-risk-of-poverty or social exclusion in 2010 and 2018 by broad group of citizenship (people at-risk-of-poverty or social exclusion by "foreign" in the year 2010 (ROP-F10) and people at-risk-of-poverty or social exclusion by "foreign" in the year 2018 (ROP-F18), people at-risk-of-poverty or social exclusion by "nationals" in the year 2010 (ROP-N10) and people at-risk-of-poverty or social exclusion by "nationals" in the year 2018 (ROP-N18)). We excluded Romania from the 28 EU countries due to the unpublished data. 
Table 1. Descriptive statistics on the indicator people at-risk-of-poverty or social exclusion in EU countries by "foreign" and "nationals".

\begin{tabular}{cccccccc}
\hline & \multicolumn{9}{c}{ Descriptive Statistics } \\
\cline { 2 - 8 } Variable & N Valid & Average & Median & Minimum & Maximum & $\begin{array}{c}\text { Standard } \\
\text { Deviation }\end{array}$ & $\begin{array}{c}\text { Variation } \\
\text { Coefficient }\end{array}$ \\
\hline ROP-F10 & 27 & 36.659 & 38.400 & 17.400 & 55.300 & 10.120 & 27.607 \\
\hline ROP-F18 & 27 & 33.248 & 34.200 & 12.700 & 54.700 & 10.499 & 31.577 \\
\hline ROP-N10 & 27 & 22.389 & 19.800 & 11.200 & 49.000 & 7.987 & 35.675 \\
\hline ROP-N18 & 27 & 19.956 & 18.800 & 11.900 & 32.000 & 5.380 & 26.959 \\
\hline
\end{tabular}

Source: own calculation according Eurostat [ilc_peps05]. Data were analyzed using software STATISTICA. Explaining abbreviations: ROPF10-people at-risk-of-poverty or social exclusion by "foreign" in the year 2010. ROP-F18-people at-risk-of-poverty or social exclusion by "foreign" in the year 2018. ROP-N10 - people at-risk-of-poverty or social exclusion by "nationals" in the year 2010. ROP-N18-people at-risk-of-poverty or social exclusion by "nationals" in the year 2018.

The average value of the indicator people at-risk-of-poverty or social exclusion in the analyzed years was significantly higher in the "foreign" group of countries than in the "nationals" group. The variability expressed by the standard deviation of the indicator at-risk-of-poverty or social exclusion was higher in the group "foreign" than in the group "nationals". The variability expressed by the coefficient of variation of the indicator at-riskof-poverty or social exclusion was lower in the group "foreign" at the beginning of the analyzed period and higher at the end of the period than in the group "nationals". In both groups, there was a decrease in average values in the analyzed period.

There was an increase in variability in the group "foreign". On the contrary, there was a significant decrease in variability in the group "nationals". Thus, from 2010 to 2018, EU countries differences between countries within the group of "nationals" have decreased. On the contrary, differences between countries within the group of "foreign" have increased. In our view, variability has increased, mainly because the number of immigrants from third countries has increased significantly in countries being detention centers for immigrants. These countries were not able to react quickly to the situation.

Descriptive statistics suggest that the average of the indicator people at-risk-of-poverty or social exclusion for both groups is declining within the EU. We can consider this development positive. The degree of variability decreased in the group "nationals". On the contrary, it increased in the group "foreign". The increase in variability in the group "foreign" indicates an increase in differences among EU countries.

In order to find out how the differences in the values regarding the indicator in the two analyzed groups have developed, we also expressed descriptive statistics regarding the differences at the beginning and at the end of the analyzed period. Descriptive statistics on differences in the indicator people at-risk-of-poverty or social exclusion are presented in Table 2. ROP-D10 is differences of the indicator people at risk of poverty or social exclusion in the year 2010 ("foreign"-"nationals"), ROP-D18 is differences of the indicator people at risk of poverty or social exclusion in the year 2018 ("foreign"-“nationals").

Table 2. Descriptive statistics on difference within the indicator people at-risk-of-poverty or social exclusion across EU countries between "foreign" and "nationals".

\begin{tabular}{cccccccc}
\hline \multirow{2}{*}{ Variable } & N Valid & Average & Median & Minimum & Maximum & $\begin{array}{c}\text { Standard } \\
\text { Deviation }\end{array}$ & $\begin{array}{c}\text { Variation } \\
\text { Coefficient }\end{array}$ \\
\cline { 2 - 8 } & 27 & 14.270 & 11.900 & -3.200 & 29.600 & 9.909 & 69.436 \\
\hline ROP-D10 & 27 & 13.293 & 12.300 & -2.300 & 33.400 & 9.290 & 69.886 \\
\hline ROP-D18 & 27 &
\end{tabular}

Source: own calculation according Eurostat [ilc_peps05]. Data were analyzed using software STATISTICA. Explaining abbreviations: ROP-D10 difference within the indicator people at-risk-of-poverty or social exclusion across EU countries between "foreign" and "nationals" in the year 2010. ROP-D18 difference within the indicator people at-risk-of-poverty or social exclusion across EU countries between "foreign" and "nationals" in the year 2018. 
The average value of the differences between the two groups dropped. The variability of differences expressed by the coefficient of variation increased slightly.

In the next step, we analyzed the specifics of the indicator people at-risk-of-poverty or social exclusion in the two analyzed groups in EU countries. In most EU countries, the value of indicator people at-risk-of-poverty or social exclusion was higher in the group "foreign" than in the "nationals" group of countries. The lower value of the indicator people at-risk-of-poverty or social exclusion within the group "foreign" in 2010 was in two countries-Bulgaria and Hungary. In 2018, the value of the indicator people at-risk-ofpoverty or social exclusion was lower within the "foreign" group of countries in Poland. The reason for the lower value of the indicator people at-risk-of-poverty or social exclusion within the group "foreign" is, in our opinion, the fact that in 2010 these countries did not indicate a significant shortage of labor. They did not focus significantly on migration policies aimed at large-scale labor recruitment. In these countries, a significant proportion of people within the group "foreign" was above the average wages level.

There are significant differences among EU countries within the levels of indicator people at-risk-of-poverty or social exclusion and the differences between the groups. The value of the indicator people at-risk-of-poverty or social exclusion in EU countries in the two analyzed groups are shown in Figures 1 and 2. The Czech Republic had the lowest values of the indicator people at-risk-of-poverty for "foreign" countries group in 2010 and 2018. The lowest values of the indicator people at-risk-of-poverty or social exclusion for "nationals" group of countries had in 2010 Luxembourg and in 2018 Czechia. The low value of the indicator people at-risk-of-poverty in the Czech Republic indicates a well-established social system. At the same time, in our opinion, the low value of the indicator people at-risk of poverty or social exclusion within the group "foreign" is also a consequence of the fact that many people from the Slovak Republic work in the Czech Republic. The advantages are similar cultural values, mentality and familiar languages. At the same time, the education system in the Czech Republic is open to Slovak citizens. They have the same approach to education as Czech citizens. That was the reason that made a large part of intelligence from the Slovak Republic remain working in more economically efficient the Czech Republic.

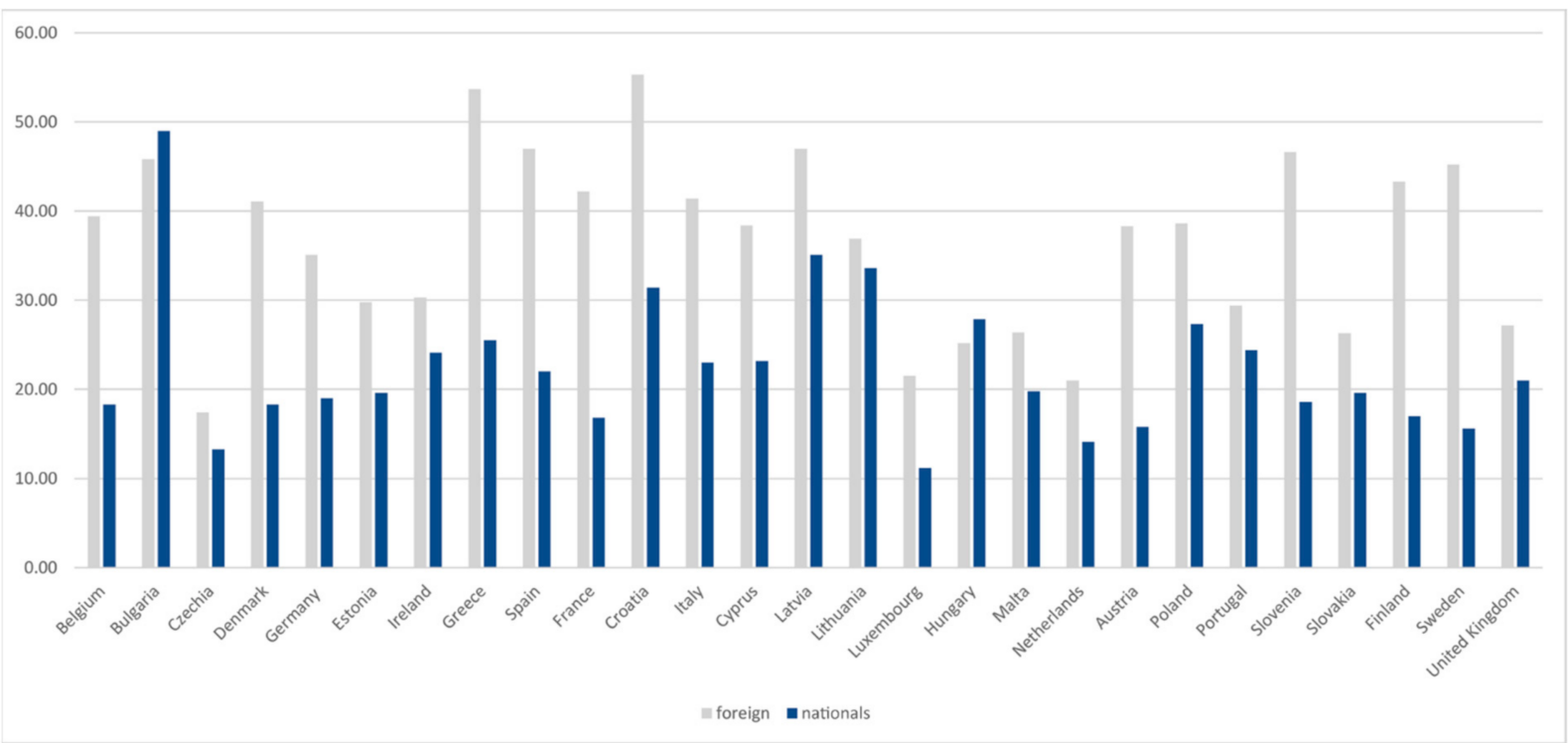

Figure 1. People at-risk-of-poverty or social exclusion in the groups "foreign" and "nationals" in 2010. Source: according Eurostat [ilc_peps05]. 




Figure 2. People at-risk-of-poverty or social exclusion in the groups "foreign" and "nationals" in 2018. Source: according Eurostat [ilc_peps05].

The biggest difference between the two groups was in 2010 and 2018 in Sweden. Sweden was opened to immigrants. According to Denník N (2016) [32], the country is considered one of the most open. Many immigrants with minor children moved to the country. However, the country did not manage the large waves of immigrants. In 2016 Sweden began to tighten its migration policy. The country has moved to expelling immigrants. The difference of indicator people at-risk-of-poverty between the groups at the people at-risk-of-poverty in Sweden is significant. It is obvious that the uncoordinated inflow of migrants has also been one of the accelerating issues when it comes to growing differences between the two groups.

Based on the differences and the dynamics of differences between the two groups by means of the basic index and the average growth coefficient calculations we can classify countries into two groups. In the group where the differences between the groups have increased are: Bulgaria, Estonia, Spain, France, Italy, Lithuania, Hungary, Malta, Netherlands, Portugal and Sweden. The largest increase in differences was in Hungary.

The group consists mainly of countries where there has been a significant increase in immigrants, both due to labor shortages and due to the large number of illegal migrants. Apart from Hungary, there was a large increase in differences in Bulgaria and the Netherlands. Hungary and Bulgaria had a negative difference at the beginning of the period. However, despite the large increase, the difference in both countries is below the average. The average annual growth of the poverty risk gap in the Netherlands was even $20 \%$. The Netherlands had a shortage of manpower and therefore accepted a large number of immigrants. The difference between the risk of poverty within the two groups doubled during the observed period.

The second group consists of countries where differences between groups have decreased. It includes all the other EU countries. The largest decrease in differences occurred in Germany and the Czech Republic. The value of the difference between the two groups in the indicator people at-risk-of-poverty or social exclusion has dropped to about $19 \%$ in those mentioned countries.

From the above executed analysis, we can summarize that even though the average poverty risk values and their differences between the two groups of countries in EU countries are declining, the variability of the indicator people at-risk-of-poverty in the group "foreign" has increased. Differences within the indicator people at-risk-of-poverty between 
the groups are large, especially in countries, which have been dealing with the large increase in immigrants from third countries-outside of the EU (Sweden, Spain, Greece).

In the next step, we estimated whether the EU countries are getting closer one another in terms of indicator values differences within the two groups. For this reason, we expressed the standard deviation of the differences within the indicator people at-risk-of-poverty between the two groups in EU countries during the observed period (Table 3).

Table 3. Standard deviation of difference between "foreign" and "nationals" within the indicator people at-risk-of-poverty or social exclusion.

\begin{tabular}{lcccccccccc}
\hline & N Valid & $\mathbf{2 0 1 0}$ & $\mathbf{2 0 1 1}$ & $\mathbf{2 0 1 2}$ & $\mathbf{2 0 1 3}$ & $\mathbf{2 0 1 4}$ & $\mathbf{2 0 1 5}$ & $\mathbf{2 0 1 6}$ & $\mathbf{2 0 1 7}$ & $\mathbf{2 0 1 8}$ \\
\hline $\begin{array}{l}\text { Standard } \\
\text { deviation }\end{array}$ & 27 & 9.909 & 8.847 & 11.573 & 10.595 & 12.249 & 11.808 & 12.269 & 9.117 & 9.290 \\
\hline
\end{tabular}

Source: own calculation according Eurostat [ilc_peps05]. Data were analyzed using software STATISTICA.

The standard deviation within the indicator difference decreased from 2010 to 2018, but the tendency of decreasing variability was not stable during the observed period.

The largest decrease in variability was recorded from 2016 to 2017 . However, the declining trend of the standard deviation of differences was not stable in the following year. In 2018, the difference variability increased slightly. In general, we can state that even though the difference variability from 2010 to 2018 decreased, the tendency the variability is to be decreased is not stable. It is also the result of uneven dynamics growth within the number of immigrants in individual EU countries.

Even though the people at-risk-of-poverty average in both groups also the average differences in indicators are declining, the variability in the group "foreign" is increasing. Inequalities within the group "foreign" have increased slightly. In our opinion, the increase in inequality was caused by the increase in the indicator people at-risk-of-poverty within the "foreign" group of countries that were very open to immigrants (e.g. Sweden) and countries with a higher risk of poverty within the "nationals" group of countries at the beginning of the observed period.

We are aware that our conclusions have certain limitations. It can be assumed that the risk of poverty depends on several factors. We consider the length of immigrants' staying in a foreign country and the economic development of the immigrants' domestic country to be among the most important factors influencing the risk of poverty and the employment of immigrants. In order to broaden our analysis on the specifics of immigrants on the basis of which group of economically developed countries they come from and on the basis of available data, in the next step we divided the "foreign" group of countries into two subgroups. In the first subgroup are foreign from outside the EU countries ("non-EU foreign") and in the second group are people from EU countries outside the reporting country ("foreign from the EU"). This kind of breakdown is also available within the Eurostat database, from which we draw data offering us a deeper look at the observed issue. However, the breakdown has certain limitations. For example, not all countries in those subgroups can be considered economically developed at the same level. However, we assume that most immigrants from outside the EU are mainly from nonEU countries and from Africa [33]. In most cases these countries can be considered less economically developed.

In the next part of our analysis, the intention is to determine the specifics of the differences between the two subgroups and the group "nationals" based on the values of the people at-risk-of-poverty or social exclusion indicator. Because of unpublished data, Bulgaria, Croatia, Lithuania, Hungary, Poland, Romania and Slovakia were excluded from the analysis. 
3.1.1. Difference in the People at-Risk-of-Poverty or Social Exclusion Indicator between the "Non-EU Foreign" Group and the "Nationals" Group

The arithmetic mean of the difference between the groups of "non-EU foreign" and "nationals" decreased from 2010 (ROPA-D10) to 2018 (ROPA-D18) (Table 4). The average level of differences therefore decreased. The highest value of the arithmetic mean in the analyzed period was in 2016.

Table 4. Descriptive statistics on difference between "non-EU foreign" and "nationals" within the indicator people at-risk-of-poverty or social exclusion across EU countries.

\begin{tabular}{cccccccc}
\hline \multirow{2}{*}{ Variable } & N Valid & Average & Median & Minimum & Maximum & $\begin{array}{c}\text { Standard } \\
\text { Deviation }\end{array}$ & $\begin{array}{c}\text { Variation } \\
\text { Coefficient }\end{array}$ \\
\cline { 2 - 9 } & 21 & 24.148 & 25.700 & 3.700 & 45.100 & 12.687 & 52.540 \\
\hline ROPA-D10 & 21 & 22.943 & 24.300 & 7.500 & 36.000 & 9.601 & 41.847 \\
\hline ROPA-D18 & & & & & & & \\
\hline
\end{tabular}

Source: own calculation according Eurostat [ilc_peps05]. Data were analyzed using software STATISTICA. Explaining abbreviations: ROPA-D10 difference between "non-EU foreign" and "nationals" in the year 2010. ROPA-D18 difference between "non-EU foreign" and "nationals" in the year 2018.

Based on the analysis of the development of the standard deviation of the difference in the values of the people at-risk-of-poverty or social exclusion indicator between the groups of "non-EU foreign" and "nationals" (Table 5), we can state the standard deviation decreased that from 2015 to 2017 . The variability of the difference among countries decreased significantly from 2010 to 2018 . We consider the trend of a decrease in the arithmetic mean of the differences and a decrease in the standard deviation to be positive. We assume that it was caused by the EU migration policy and EU subsidies provided to EU countries to handle the inflow of large number of migrants.

Table 5. Standard deviation of difference between "non-EU foreign" and "nationals" within the indicator people at-risk-ofpoverty or social exclusion.

\begin{tabular}{lcccccccccc}
\hline & N Valid & $\mathbf{2 0 1 0}$ & $\mathbf{2 0 1 1}$ & $\mathbf{2 0 1 2}$ & $\mathbf{2 0 1 3}$ & $\mathbf{2 0 1 4}$ & $\mathbf{2 0 1 5}$ & $\mathbf{2 0 1 6}$ & $\mathbf{2 0 1 7}$ & $\mathbf{2 0 1 8}$ \\
\hline $\begin{array}{l}\text { Standard } \\
\text { deviation }\end{array}$ & 21 & 12.687 & 12.867 & 11.300 & 10.556 & 11.121 & 11.670 & 10.250 & 8.778 & 9.601 \\
\hline
\end{tabular}

Source: own calculation according Eurostat [ilc_peps05]. Data were analyzed using software STATISTICA.

3.1.2. Difference in the People at-Risk-of-Poverty or Social Exclusion Indicator between the Group "Foreign from the EU" and the "Nationals" Group

From 2010 (ROPB-D10) to 2018 (ROPB-D10) the arithmetic mean of the difference between the groups "foreign from the EU" and "nationals" is significantly smaller than the arithmetic mean of the difference between the group "non-EU foreign" and the "nationals" group.

At the same time, obviously the arithmetic mean of the difference between the group "foreign from the EU" and the "nationals" group has decreased. Thus, the average level of differences decreased (Table 6). The highest value of the arithmetic mean in the analyzed period was in 2016.

In the next step, we observed the development of the standard deviation of the difference in the values of the people at-risk-of-poverty or social exclusion indicator between the group "foreign from the EU" and between the "nationals" group (Table 7). We can state that the development of the standard deviation was not stable. From 2010 to 2018, the variability of the difference increased. This development was also influenced by the increase in the number of EU countries that had a higher value of the people at-risk-of-poverty or social exclusion indicator in the "nationals" group than in the group "foreign from the EU". In our opinion, this is also because immigrants from the EU mostly work to a lesser extent in work positions that are less paid and "nationals" are not interested in those work positions. 
Table 6. Descriptive statistics on difference between "foreign from the EU" and "nationals" within the indicator people at-risk-of-poverty or social exclusion across EU countries.

\begin{tabular}{cccccccc}
\hline & \multicolumn{7}{c}{ Descriptive Statistics } \\
\cline { 2 - 8 } Variable & N Valid & Average & Median & Minimum & Maximum & $\begin{array}{c}\text { Standard } \\
\text { Deviation }\end{array}$ & $\begin{array}{c}\text { Variation } \\
\text { Coefficient }\end{array}$ \\
\hline ROPB-D10 & 21 & 8.814 & 7.600 & -1.000 & 19.700 & 5.972 & 62.756 \\
\hline ROPB-D18 & 21 & 6.886 & 6.800 & -12.300 & 24.600 & 8.927 & 129.640 \\
\hline
\end{tabular}

Source: own calculation according Eurostat [ilc_peps05]. Data were analyzed using software STATISTICA. Explaining abbreviations: ROPB-D10 difference between "foreign from the EU" and "nationals" in the year 2010. ROPB-D18 difference between "foreign from the EU" and "nationals" in the year 2018.

Table 7. Standard deviation of difference between "foreign from the EU" and "nationals" within the indicator people at-risk-of-poverty or social exclusion.

\begin{tabular}{ccccccccccc}
\hline & N Valid & $\mathbf{2 0 1 0}$ & $\mathbf{2 0 1 1}$ & $\mathbf{2 0 1 2}$ & $\mathbf{2 0 1 3}$ & $\mathbf{2 0 1 4}$ & $\mathbf{2 0 1 5}$ & $\mathbf{2 0 1 6}$ & $\mathbf{2 0 1 7}$ & $\mathbf{2 0 1 8}$ \\
\hline $\begin{array}{l}\text { Standard } \\
\text { deviation }\end{array}$ & 21 & 5.972 & 6.928 & 7.904 & 10.021 & 9.816 & 8.353 & 7.364 & 9.315 & 8.927 \\
\hline
\end{tabular}

Source: own calculation according Eurostat [ilc_peps05]. Data were analyzed using software STATISTICA.

It follows from the above that by comparing the values of the differences in the indicator people at-risk-of-poverty or social exclusion between the group "non-EU foreign" and the "nationals" group and by comparing the differences in the values of the indicator people at-risk-of-poverty or social exclusion in the group "foreign from the EU" and in the "nationals" group, it is obvious that immigrants outside the EU are significantly at higher risk of poverty. At the same time, a new trend in the EU is beginning to emerge in relation to the risk of poverty; the number of EU countries with domestic population at risk of poverty being higher than EU immigrants is increasing.

\subsection{Employment}

In the following section, we focus on the specification of inequality between domestic and immigrant populations in the field of employment in EU countries. Table 8 describes descriptive employment rate statistics in 2010 and 2018 by broad group of citizenship(employment rate by "foreign" in the year 2010 (ER-F10), employment rate by foreign in the year 2018 (ER-F18), employment rate by "nationals" in the year 2010 (ER-N10), employment rate by "nationals" in the year 2018 (ER-N18)). We have excluded Romania due to unpublished data.

Table 8. Descriptive statistics on the employment rate by "nationals" and "foreign" in EU countries.

\begin{tabular}{cccccccc}
\hline & \multicolumn{7}{c}{ Descriptive Statistics } \\
\cline { 2 - 8 } Variable & N Valid & Average & Median & Minimum & Maximum & $\begin{array}{c}\text { Standard } \\
\text { Deviation }\end{array}$ & $\begin{array}{c}\text { Variation } \\
\text { Coefficient }\end{array}$ \\
\hline ER-F10 & 27 & 58.811 & 59.400 & 32.300 & 74.600 & 8.367 & 14.228 \\
\hline ER-F18 & 27 & 65.541 & 65.900 & 51.800 & 81.200 & 7.667 & 11.697 \\
\hline ER-N10 & 27 & 63.633 & 62.500 & 54.900 & 74.600 & 5.966 & 9.376 \\
\hline ER-N18 & 27 & 69.596 & 69.700 & 55.100 & 79.400 & 6.074 & 8.728 \\
\hline
\end{tabular}

Source: own calculation according Eurostat [lfsa_ergan]. Data were analyzed using software STATISTICA. Explaining abbreviations: ER-F10 employment rate by "foreign" in the year 2010. ER-F18 employment rate by "foreign" in the year 2018. ER-N10 employment rate by "nationals" in the year 2010. ER-N18 employment rate by "nationals" in the year 2018.

The average value of the employment rate indicator was lower in the group "foreign" than in the group "nationals". In both groups, the average value increased during the 
observed period, being considered a positive trend. The variability expressed by the coefficient of variation has decreased in both groups.

Descriptive statistics suggests that the average employment rate for both groups is rising across the EU and the variability among EU countries is declining.

Descriptive statistics within the employment rate differences between the two groups in both two years are presented in Table 9. ER-D10 is differences of employment rate in the year 2010 ("nationals"-“foreign"). ER-D18 is differences ("nationals"-"foreign") of employment rate in the year 2018.

Table 9. Descriptive statistics of employment rate difference between "nationals" and "foreign" in EU countries

\begin{tabular}{cccccccc}
\hline & \multicolumn{7}{c}{ Descriptive Statistics } \\
\cline { 2 - 8 } Variable & N Valid & Average & Median & Minimum & Maximum & $\begin{array}{c}\text { Standard } \\
\text { Deviation }\end{array}$ & $\begin{array}{c}\text { Variation } \\
\text { Coefficient }\end{array}$ \\
\hline ER-D10 & 27 & 4.822 & 4.700 & -9.700 & 25.200 & 8.908 & 184.728 \\
\hline ER-D18 & 27 & 4.056 & 3.300 & -8.500 & 20.600 & 7.823 & 192.897 \\
\hline
\end{tabular}

Source: own calculation according Eurostat [lfsa_ergan]. Data were analyzed using software STATISTICA. Explaining abbreviations: ER-D10 employment rate between "nationals" and "foreign" in the year 2010. ER-D18 employment rate between "nationals" and "foreign" in the year 2018.

The average value of employment rate differences between the two groups has decreased. The average value of the difference was increasing from 2014 to 2015 and from 2015 to 2016. From 2016, it began to decline. It dropped below the average level of differences in 2010. Thus, especially in the last three years of the observed period, we can talk about a decrease in differences in employment rate between the analyzed groups. The variability of employment rate differences, expressed as a coefficient of variation, has increased.

In the next step, we analyzed the specifics of employment rate. The employment rate in EU countries in the two analyzed groups is presented by Figures 3 and 4 There are significant differences in employment rate levels and in differences between the groups among EU countries. The minimum employment rate in the group "foreign" in 2010 can be seen in Croatia, the maximum in Czech Republic. The minimum employment rate in the group "foreign" was reached in 2018 in Greece, the maximum value in Czech Republic.

The minimum employment rate in the group "nationals" was reached in 2010 in Hungary, the maximum value in the Netherlands. The minimum employment rate in the group "nationals" was reached in 2018 in Greece, the maximum in Sweden. It can be implied that the employment rate in Czech Republic is very high. As we have already said, this country has a very well-established social system and migration policy. It can certainly be a good example for other EU countries.

The biggest differences in employment rate between the groups were in 2010 in Croatia, in 2018 in Sweden. In Croatia, there were observed large fluctuations in employment rate within the group "foreign". However, at the end of the observed period, the employment rate in this group increased significantly.

The standard deviation within the employment rate difference in the two groups (Table 10) has been declining since 2013. We consider this trend positive, along with the growing average values of employment rate in both groups and the decrease in average difference.

To broaden the analysis, we divided the group "foreign" into two subgroups, in the same way as analyzing the risk of poverty and employment rate. In the first subgroup there are foreign from outside the EU ("non-EU foreign") and in the second group there are "foreign from the EU". Our intention is to determine the specifics of the differences between the "nationals" group and between the two subgroups. Because of unpublished data, Romania, Croatia, Slovakia, Bulgaria, Latvia and Lithuania were excluded from the analysis. 


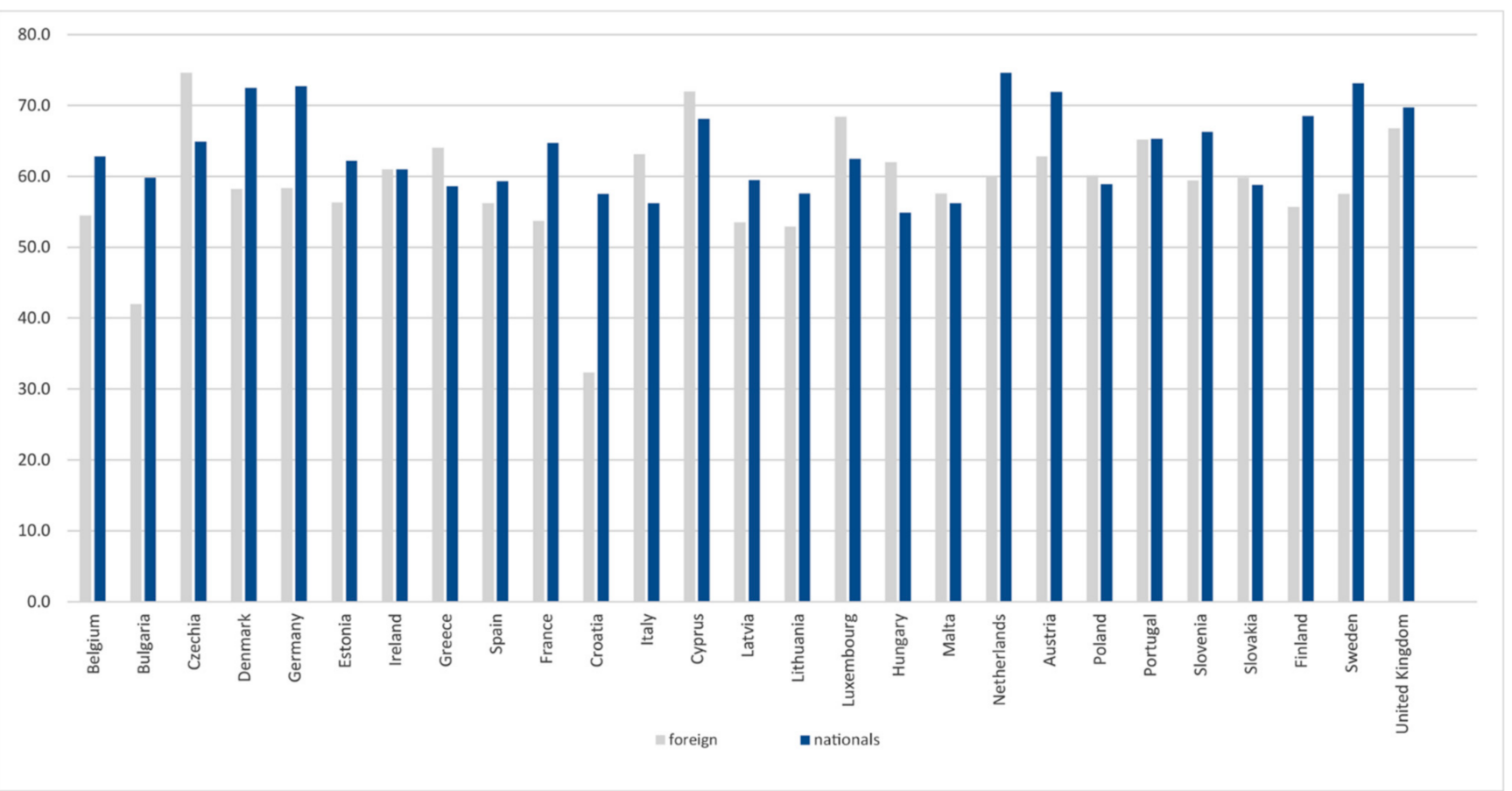

Figure 3. Employment rate in \% in groups "nationals" and "foreign" in 2010. Source: According Eurostat [lfsa_ergan].

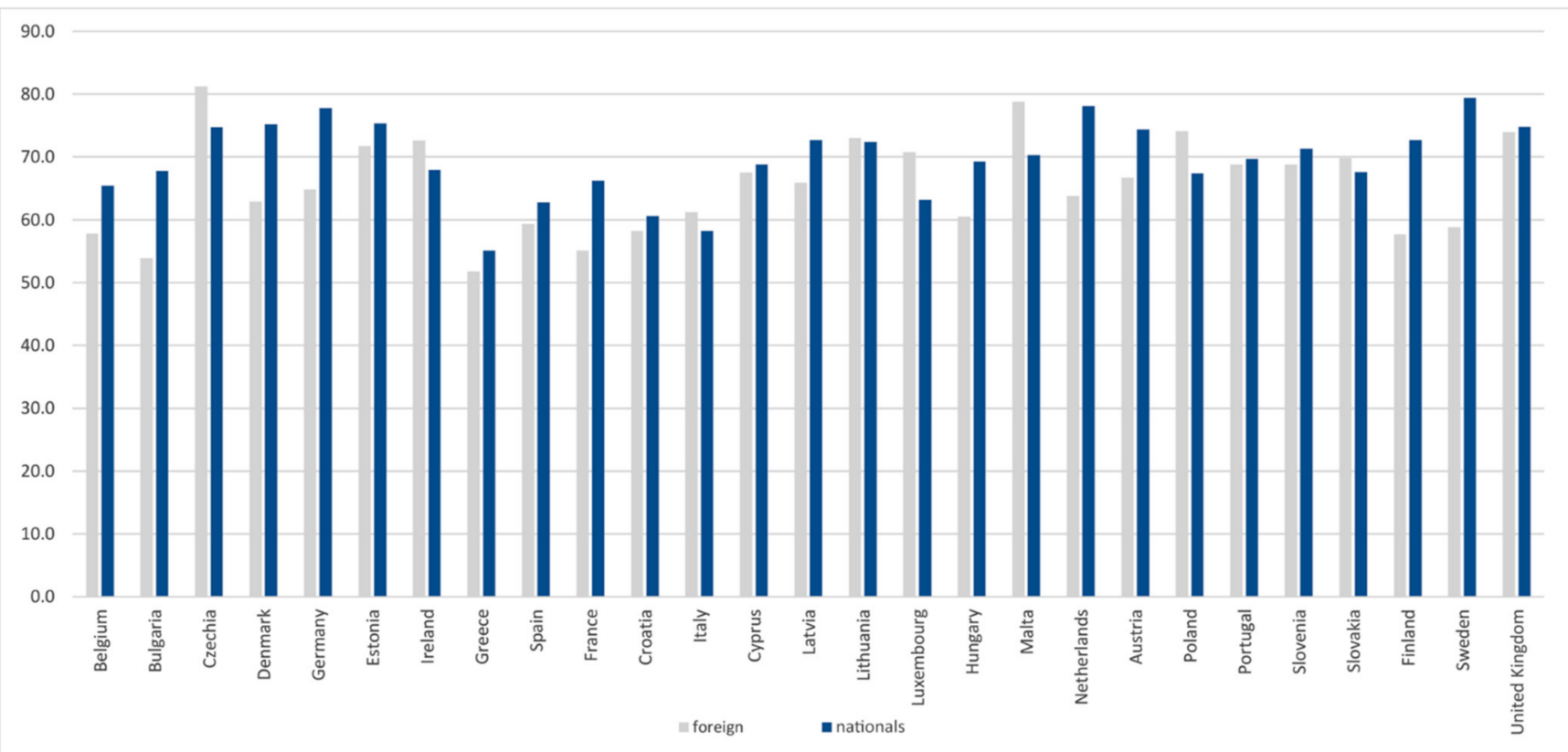

Figure 4. Employment rate in groups "nationals" and "foreign" in \% in 2018. Source: According Eurostat [lfsa_ergan].

Table 10. Standard deviation of the difference between "nationals" and "foreign" within the employment rate

\begin{tabular}{lcccccccccc}
\hline & N Valid & $\mathbf{2 0 1 0}$ & $\mathbf{2 0 1 1}$ & $\mathbf{2 0 1 2}$ & $\mathbf{2 0 1 3}$ & $\mathbf{2 0 1 4}$ & $\mathbf{2 0 1 5}$ & $\mathbf{2 0 1 6}$ & $\mathbf{2 0 1 7}$ & $\mathbf{2 0 1 8}$ \\
\hline $\begin{array}{l}\text { Standard } \\
\text { deviation }\end{array}$ & 27 & 8.908 & 8.098 & 8.921 & 9.674 & 9.426 & 8.934 & 8.400 & 8.351 & 7.823 \\
\hline
\end{tabular}


3.2.1. Difference in the Employment Rate between the "Nationals" Group and the Group "Non-EU Foreign"

From 2010 (ERA-D10) to 2018 (ERA-D18) the arithmetic mean of the difference between the "nationals" group and the group "non-EU foreign" increased. Thus, the average level of differences has increased (Table 11). The highest value of the arithmetic mean in the analyzed period was in 2016.

Table 11. Descriptive statistics of employment rate difference between "nationals" and "non-EU foreign" in EU countries.

\begin{tabular}{cccccccc}
\hline \multirow{2}{*}{ Variable } & N Valid & Average & Median & Minimum & Maximum & $\begin{array}{c}\text { Standard } \\
\text { Deviation }\end{array}$ & $\begin{array}{c}\text { Variation } \\
\text { Coefficient }\end{array}$ \\
\cline { 2 - 8 } & 22 & 8.782 & 6.200 & -6.000 & 28.500 & 11.147 & 126.927 \\
\hline ERA-D10 & 22 & 10.168 & 8.400 & -7.300 & 30.300 & 10.944 \\
\hline ERA-D18 & 22 & & & & \multicolumn{7}{c}{ Descriptive Statistics } \\
\hline
\end{tabular}

Source: own calculation according Eurostat [lfsa_ergan]. Data were analyzed using software STATISTICA. Explaining abbreviations: ERA-D10 rate difference between "nationals" and "non-EU foreign" in the year 2010. ERA-D18 rate difference between "nationals" and "non-EU foreign" in the year 2018.

Based on the analysis of the standard deviation of the difference in the employment rate values between the "nationals" group and the group "non-EU foreign" (Table 12), we can state that from 2013 to 2017 the standard deviation decreased. The variability of the difference among countries has decreased significantly since 2013. We do not consider the trend of increasing arithmetic mean of differences to be positive. In our view, it is also the result of an uncoordinated inflow of huge number of immigrants from the non-EU member countries.

Table 12. Standard deviation of difference between "nationals" and "non-EU foreign" within the indicator employment rate in EU countries.

\begin{tabular}{ccccccccccc}
\hline & N valid & $\mathbf{2 0 1 0}$ & $\mathbf{2 0 1 1}$ & $\mathbf{2 0 1 2}$ & $\mathbf{2 0 1 3}$ & $\mathbf{2 0 1 4}$ & $\mathbf{2 0 1 5}$ & $\mathbf{2 0 1 6}$ & $\mathbf{2 0 1 7}$ & $\mathbf{2 0 1 8}$ \\
\hline $\begin{array}{l}\text { Standard } \\
\text { deviation }\end{array}$ & 22 & 11.147 & 11.516 & 12.862 & 13.114 & 12.932 & 12.004 & 11.506 & 10.867 & 10.944 \\
\hline
\end{tabular}

Source: own calculation according Eurostat [lfsa_ergan]. Data were analyzed using software STATISTICA.

3.2.2. Difference in the Employment Rate between the "Nationals" Group and the Group "Foreign from the EU"

The difference between the employment rate in the "nationals" group and the group "foreign from the EU" is in most cases negative. This finding is very interesting. Thus, in most EU countries, the employment rate in the "nationals" group is lower than in the group "foreign from the EU". The arithmetic mean of the difference between the "nationals" group and the group "foreign from the EU" in 2010 (ERB-D10) and in 2018 (ERB-D18) was negative (Table 13).

Table 13. Descriptive statistics of employment rate difference between "nationals" and "foreign from the EU" in EU countries.

\begin{tabular}{cccccccc}
\hline & \multicolumn{8}{c}{ Descriptive Statistics } \\
\cline { 2 - 9 } Variable & N Valid & Average & Median & Minimum & Maximum & $\begin{array}{c}\text { Standard } \\
\text { Deviation }\end{array}$ & $\begin{array}{c}\text { Variation } \\
\text { Coefficient }\end{array}$ \\
\hline ERB-D10 & 22 & -2.241 & -0.250 & -13.500 & 30.900 & 5.329 & -237.823 \\
\hline ERB-D18 & 22 & -3.268 & -1.100 & -19.000 & 30.300 & 5.956 & -182.256 \\
\hline
\end{tabular}

Source: own calculation according Eurostat [lfsa_ergan]. Data were analyzed using software STATISTICA. Explaining abbreviations: ERB-D10 rate difference between "nationals" and "foreign from the EU" in the year 2010. ERB-D18 rate difference between "nationals" and "foreign from the EU" in the year 2018. 
In the next step, we observe the development of the standard deviation of the difference in the employment rate values between the "nationals" group and the group "foreign from the EU" (Table 14). We can state that the development of the standard deviation was not stable. Thus, the analyzed countries did not systematically move closer within the values of differences between the groups.

Table 14. Standard deviation of difference between "nationals" and "foreign from the EU" within the indicator employment rate in EU countries.

\begin{tabular}{lcccccccccc}
\hline & N Valid & $\mathbf{2 0 1 0}$ & $\mathbf{2 0 1 1}$ & $\mathbf{2 0 1 2}$ & $\mathbf{2 0 1 3}$ & $\mathbf{2 0 1 4}$ & $\mathbf{2 0 1 5}$ & $\mathbf{2 0 1 6}$ & $\mathbf{2 0 1 7}$ & $\mathbf{2 0 1 8}$ \\
\hline $\begin{array}{l}\text { Standard } \\
\text { deviation }\end{array}$ & 22 & 5.329 & 6.069 & 5.919 & 5.744 & 4.682 & 5.987 & 4.107 & 5.309 & 5.956 \\
\hline
\end{tabular}

Source: own calculation according Eurostat [lfsa_ergan]. Data were analyzed using software STATISTICA.

It follows from the above that by comparing the employment rate in the "nationals" group and group "non-EU foreign" and comparing the employment rate in the "nationals" group and the group "foreign from the EU", it is clear that most EU countries have higher employment rate within the group "foreign from the EU" and vice versa most EU countries have a higher employment rate within the "nationals" group than "non-EU foreign" group. The reduction of the differences in the employment rate between the "nationals" and "foreign" groups was mainly influenced by the reduction of the differences between the "nationals" group and "non-EU foreign" group.

From the decrease in the arithmetic mean of the difference between people at-risk-ofpoverty or social exclusion between the group "nationals" and group "non-EU foreign" and from the increase in the arithmetic average of the employment rate difference between the group "nationals" and group "non-EU foreign", we can conclude that the EU subsidies helped reduce poverty risk for non-EU immigrants, however, the gap within the employment rate did not get smaller. The EU labor market was not prepared for a large unsystematic inflow of immigrants from third countries within such a short period of time (especially in 2015 and 2016).

\subsection{Discussion}

This study deals with the changes of inequalities within poverty and employment between domestic population and immigrants. The group of domestic population is represented by people from a reporting country (country of citizenship). The group of immigrants is represented by people from foreign countries (country of citizenship).

In our study we collected data from $[26,27]$. We have analyzed the specifics of individual EU countries, the development of changes that occurred in inequalities between the two groups in terms of poverty and employment, along with their dynamics and convergence trends. Like the Eurostat source [34] this study also has showed that the risk of poverty or social exclusion in the EU was lower in the group of "nationals" than among immigrants.

Immigrants are therefore more at poverty risk than domestic population. The high values of people at-risk-of-poverty indicator or social exclusion are mainly in countries, where many refugees from third countries came to during the period under review (Greece, Spain). There are several reasons for that. One of the main reasons, in our view, is the fact that the social status of immigrants is significantly affected by the length of time they are staying in the country to which they have immigrated. Emigrants who are staying in the destination country for a short time are at poverty risk the most. The issue of the economic development of immigrants' domestic country is another important factor to be assessed. After dividing the foreign group into two subgroups- "foreign from the EU" and foreign outside the EU ("non-EU foreign"), we noted that when it comes to the risk of poverty, immigrants outside the EU are more at risk. At the same time, a new trend in the $\mathrm{EU}$ is beginning to emerge regarding the risk of poverty; the number of EU countries with domestic population at risk of poverty being higher than EU immigrants is increasing. 
In our view, EU subsidies and EU and national migration policies have played an important role that immigrants were jeopardized by the risk of poverty. Only the combination of these two elements made the risk of poverty not to be increased significantly, even with such a large increase in the number of immigrants, especially in 2015 and 2016.

Nowadays, EU migration policies are mainly focused on the acquisition of labor force. In our opinion, not only policies supporting the employment of the immigrants but also policies supporting the integration of immigrants need to be taken into account in order to decrease differences between immigrants and domestic population.

Complex integration policy for immigrants can largely help in poverty reduction and social inclusion of immigrants. Comparison of the EU countries' immigrants inclusion policies have not been the subject of this study but can be an opportunity for further research.

During the period under review, there was also an increase in the employment rate of domestic population and immigrants. The average value of employment rate increased in both groups- "foreign" and "nationals". However, the average value of employment rate was lower in the group "foreign" than in the group "nationals".

However, if we observe the group "foreign" divided into two subgroups, then most $\mathrm{EU}$ countries have a higher employment rate in the group "foreign from the EU" than in the "nationals" group and, conversely, most EU countries have a higher employment rate in the" nationals" group than in "non-EU foreign" group. It can be concluded that, although EU subsidies have had a positive effect on the risk of poverty for non-EU immigrants in EU countries, more time was necessary to get them integrate into the labor market in terms of employment in countries with a large inflow of immigrants outside the EU. EU countries could have been negatively affected within their economic outcomes.

In our study, we point to an important phenomenon today, which is the reduction of disparities within the poverty risk and employment between the domestic population and immigrants. This is also evidenced by the decrease in the arithmetic mean of the differences in the two analyzed indicators. This trend is mainly the result of labor shortage and labor market needs. Even though governments are increasing the retirement age, in many areas there is still a shortage of labor. Immigration plays an important role within the labor shortage issue [35]. In the study, we also deal with convergence trends. For this reason, we also expressed a standard deviation. Based on the standard deviation values, we can confirm the decrease in variability within the group "nationals" in case of both indicators. On the other hand, in the group "foreign", in terms of the people at-risk-of-poverty indicator or social exclusion, the variability increased. Since 2013, convergence trends within the employment rate have also been confirmed based on the standard deviation values.

Within the specifics of individual EU countries, we affirmed a very good position of Czech Republic when it comes to a high employment rate in both analyzed groups as well as a low at-risk-of-poverty rate value. The employment rate in the group "foreign" was higher than in the group "nationals". At the same time, in the analyzed period there was a significant decrease in the differences within the at-risk-of-poverty rate level between the two groups. In our opinion, this result is also because Czech Republic is also open to students from Slovak Republic in higher education. Slovak graduates from Czech universities usually stay in Czech Republic. Authors Čuhlová, Potužáková (2017) have a similar opinion [36]. Czech Republic has an excellent position in Central and Eastern Europe in terms of its capacity for development, attraction and retaining of talent. According to Čuhlová, Potužáková (2017, p. 163) "within benchmarked categories of talent environment, openness (for example hiring of foreign nationals), quality of the labor force, proclivity to attracting talent with consideration of demographics and education, Czech Republic reached the best ranking among countries from the region of Central and Eastern Europe" [36].

There are several factors that affect immigrant poverty and employment. However, in our study we do not deal in detail with the impact of each of them. This is the issue we would like to focus on in the next study. 
In our opinion, big differences between the groups within the analyzed indicators were evident mainly in countries that had a large inflow of illegal migrants from third countries. In these countries, labor immigration has had little benefit in the short term. This statement does not deny the statement of De Luna Gallardo, Korneeva, Strielkowski [37]. According to them if the domestic population has the same skills as immigrants, the domestic population will not benefit from immigration.

\section{Conclusions}

The aim of the study was to confirm, based on analyzes, the expected declining trends within the differences between domestic population and immigrants in terms of their social status, and to determine the specifics of inequalities between domestic and immigrant population in terms of their social status in the EU. In the study, we have determined the specifics of the differences. We determined the dynamics of change and evaluated the convergence tendencies.

In the EU, the average value of the indicator people at-risk-of-poverty or social exclusion is declining for both groups. The important fact is that the average differences between the two groups have been narrowed. The degree of variability decreased in the group "nationals". Thus, in 2018, the differences among EU countries in the values of people at-risk-of-poverty indicator or social exclusion were smaller than in 2010.

On the contrary, it increased in the group "foreign". In most EU countries, the value of indicator people at-risk-of-poverty or social exclusion was higher in the group of "foreign" than in the group of "nationals". The Czech Republic had the lowest values of the indicator people at-risk-of-poverty or social exclusion indicator within the group "foreign" in 2010 and in 2018. The lowest values of the indicator people at-risk-of-poverty or social exclusion within the group "nationals" were in 2010 in Luxembourg and in 2018 the Czech Republic. Positive results in the Czech Republic are reflected by the fact that many people from Slovak Republic, who are studying in Czechia will then stay working there. The biggest difference between the two groups was in Sweden. Sweden was open to immigrants and the uncoordinated inflow of migrants caused widening the differences between the two groups. Differences in the indicator people at-risk-of-poverty or social exclusion have increased in Bulgaria, Estonia, Spain, France, Italy, Lithuania, Hungary, Malta, the Netherlands, Portugal and Sweden. This group consists mainly of countries where there has been a significant increase in immigrants, both due to labor shortages and due to the large number of illegal migrants. Differences within the level of the indicator people at-riskof-poverty or social exclusion between the groups are significant especially in countries, dealing with a large increase in immigrants from the third countries. The variability of difference between the groups decreased during the observed period, but the tendency to variability decrease is not stable. It is also the result of the uneven dynamics growth of immigrants in individual EU countries.

The average value of the employment rate for both groups has increased and the variability among EU countries has decreased. The minimum employment rate in the group "foreign" was in Croatia in 2010, the maximum was in the Czech Republic. The minimum employment rate in the group "foreign" was in Greece in 2018, the maximum value in the Czech Republic. The minimum employment rate in the group "was in Hungary in 2010, the maximum value in the Netherlands. The minimum employment rate in the group "nationals" was in Greece in 2018, the maximum in Sweden. It follows from the stated above that the employment rate in the Czech Republic is very high in both groups. The Czech Republic has a very well-established social system, education system and migration policy. It can certainly be a good example for other EU countries.

The standard deviation of difference within the employment rate in the two groups has been declining since 2013. This indicates that EU countries are getting closer one another in terms of employment differences between the two groups. At the same time, the average of differences has decreased. This trend is growing and is the result of migration policies setting being aimed at recruiting a workforce that meets the requirements of 
employers. On the other hand, if immigrants come to EU countries in an uncoordinated way it may increase differences between the groups. That is why, in our view, targeted labor immigration and its support are important.

When processing the issue, we realized that there are significant differences within this analyzed issue between immigrants from the EU (within the EU Member countries) and immigrants outside the EU (from third countries). For this reason, we compared the differences between the "nationals" group and the "foreign" group from the EU ("foreign from the EU") and between the "nationals" group and the "foreign" group outside the EU ("non-EU foreign"). We found out the specifics of these differences. Immigrants outside the EU are at significantly higher risk of poverty. At the same time, a new trend in the EU is beginning to emerge in relation to the risk of poverty; the number of EU countries with domestic population at risk of poverty being higher than immigrants from the EU is increasing. In terms of employment, we can say that in most EU countries, the employment rate in the "nationals" group is lower than in group "foreign from the EU".

In our research, we processed data available from Eurostat databases. We are aware that our research has various limitations, such as the impact of length of stay in the country of immigration on the employment of immigrants and their poverty risk. Our effort is to gradually supplement the processed analyzes in further research and thus expand the knowledge in the researched area.

Author Contributions: Writing-review \& editing, E.I. and E.G. All authors have read and agreed to the published version of the manuscript.

Funding: This research was supported by the Ministry of Education, Science, Research and Sport of the Slovak Republic [grant VEGA 1/0689/20 Digital economy and changes in the education system to reflect labour market demands].

Institutional Review Board Statement: Not applicable.

Informed Consent Statement: Not applicable.

Data Availability Statement: Not applicable.

Conflicts of Interest: The authors declare no conflict of interest.

\section{References}

1. European Parliament. Free Movement of Workers. 2018. Available online: https://www.europarl.europa.eu/factsheets/en/ sheet/41/free-movement-of-workers (accessed on 10 December 2020).

2. Grmanová, E.; Kostrová, J.; Škrovánková, K. Demographic Changes and Their Impact on the Labor Market; TnUAD: Trenčín, Slovakia, 2018.

3. Marois, G.; Bélanger, A.; Lutz, W. Population aging, migration, and productivity in Europe. Proc. Natl. Acad. Sci. USA 2020, 117, 7690-7695. [CrossRef]

4. Harper, S. The Important Role of Migration for an Ageing Nation. Popul. Ageing 2016, 9, 183-189. [CrossRef]

5. Grossmann, V. How Immigration Affects Investment and Productivity in Host and Home Countries. IZA World of Labor. 2016. Available online: https:/ / wol.iza.org/articles/how-immigration-affects-investment-and-productivity-in-host-and-homecountries/long (accessed on 30 January 2021).

6. Czaika, M.; Reinprecht, C. Drivers of Migration: A Synthesis of Knowledge, IMI WP 163. 2020. Available online: https: / / www.migrationinstitute.org/publications/drivers-of-migration-a-synthesis-of-knowledge (accessed on 15 October 2020).

7. Castelli, F. Drivers of migration: Why do people move? J. Travel Med. 2018, 25, 89-102. [CrossRef]

8. Eugster, B. Immigrants and poverty, and conditionality of immigrants' social rights. J. Eur. Soc. Policy 2018, 28, 452-470. [CrossRef]

9. Haas, H.; Czaika, M.; Flahaux, M.L.; Mahendra, E.; Natter, K.; Vezzoli, S.; Villares-Varela, M. International Migration: Trends, Determinants, and Policy Effects. Popul. Dev. Rev. 2019, 45, 105-118. [CrossRef]

10. Anderson, K.H.; Huang, Z. Can Immigrants Ever Earn as Much as Native Workers? 2019. Available online: https:/ /wol.iza.org/ uploads/articles/482/pdfs/can-immigrants-ever-earn-as-much-as-native-workers.pdf (accessed on 3 February 2021).

11. Frattini, T. Integration of Immigrants in Host Countries. What We Know and What Works. Revue D'économie du Développement. 2017. Available online: https://www.cairn-int.info/journal-revue-d-economie-du-developpement-2017-1.htm (accessed on 30 January 2021).

12. Koišová, E.; Habánik, J.; Masárová, J.; Ivanová, E.; Gullerová, M. Labour Market as a Key Determinant of Human Resource Development in the Regions of the Visegrad Group; Centre of Sociological Research Szecin: Szecin, Poland, 2018; 293p.

13. OECD/ILO. How Immigrants Contribute to Developing Countries' Economies; OECD Publishing: Paris, France, 2018. [CrossRef] 
14. Cristescu, A.; Stänilä, L.; Popescu, A.M. Causal Disparities of Poverty and Unemployment in the EU. J. East. Eur. Res. Bus. Econ. 2013, 1-12. [CrossRef]

15. Dauderstäd, M. Addressing Poverty and Inequality in Europe. 2019. Available online: https://www.socialeurope.eu/povertyand-inequality-in-europe (accessed on 5 October 2020).

16. Lyubimov, I. Income inequality revisited 60 years later: Piketty vs Kuznets. Russ. J. Econ. 2017, 3, 42-53. [CrossRef]

17. Pikkety, T. Capital and Ideology; Goldhammer, A., Translator; Belknap Press World; Harvard University Press: Cambridge, MA, USA, 2019; 1104p., ISBN 9780674980822.

18. Koišová, E.; Masárová, J.; Habánik, J. Regional differences in the labour market in Slovakia and the Czech Republic, 2018. J. Compet. 2018, 10, 104-117.

19. European Commission. Impact of Brain Drain-EU Demographic Scenarios. 2019. Available online: https://ec.europa.eu/jrc/ en/facts4eufuture/eu-demographic-scenarios/impact-brain-drain (accessed on 10 October 2020).

20. Vallejo, J.A.; Lisa, A.; Keister, L.A. Immigrants and wealth attainment: Migration, inequality, and integration. J. Ethn. Migr. Stud. 2019, 46, 3745-3761. [CrossRef]

21. European Commission. General Report on the Activities of the European Union-2010. 2011. Available online: https:/ / ec.europa. eu/eurostat/web/population-demography-migration-projections/data (accessed on 10 October 2020).

22. Simpson, N. Demographic and economic determinants of migration. IZA World Labor 2017, 373. [CrossRef]

23. Giulietti, C. The Welfare Magnet Hypothesis and the Welfare Take-Up of Migrants. IZA World of Labor. 2014. Available online: https:/ / wol.iza.org/articles/welfare-magnet-hypothesis-and-welfare-take-up-of-migrants/long (accessed on 15 January 2020).

24. Cebolla-Boado, H.; Miyar-Busto, M. Are They Deterred by Welfare? Digging into the Drivers of Highly Skilled Temporary and Long-term Migrants in Europe. Int. Migr. 2019, 58, 180-204. [CrossRef]

25. Eurostat. Dataset Details. (Eurostat, 2020, 1). Available online: https://ec.europa.eu/eurostat/web/products-datasets/-/t2020_ 50\&lang=en (accessed on 15 November 2020).

26. Eurostat. Database [ilc_peps05] (Eurostat, 2020, 2). Available online: https://appsso.eurostat.ec.europa.eu/nui/show.do? dataset=ilc_peps05\&lang=en (accessed on 15 October 2020).

27. Eurostat. Database [lfsa_ergan] (Eurostat, 2020,3). Available online: https://appsso.eurostat.ec.europa.eu/nui/submitViewTableAction. do (accessed on 22 October 2020).

28. Pacáková, V.; Pardelová, R.; Rublíková, E.; Sodomová, E.; Šoltés, E. Statistics for Economists; IURA EDITION: Bratislava, Slovakia, 2003.

29. Minařík, B.; Borůvková, J.; Vystrčil, M. Analysis in Regional Development; Professional Publishing: Praha, Czech Republic, 2013.

30. Monfort, P. Convergence of EU Regions. Measures and Evolution. Working Papers. Available online: https://ec.europa.eu/ regional_policy/sources/docgener/work/200801_convergence.pdf (accessed on 8 February 2021).

31. Sala-i-Martin, X. Regional Cohesion: Evidence and Theories of Regional Growth and Convergence. Discussion Papers 10-1-1994. 1994. Available online: https:/ / elischolar.library.yale.edu/cgi/viewcontent.cgi?article=1723\&context=egcenter-discussion-paperseries (accessed on 8 February 2021).

32. Denník, N. Swedish-Exile-60-Thousand-Migrants. Available online: https://dennikn.sk/355154/svedsko-vyhosti-60-tisicmigrantov / (accessed on 10 October 2020).

33. OECD; EU. Recruiting Immigrant Workers: Europe 2016. OECD Publishing. 2016. Available online: https://www.oecd.org/els/ mig/Recruiting-Immigrant-Workers-Europe-Recommendations_Slovak.pdf (accessed on 12 December 2020).

34. Eurostat. Migrant Integration Statistics-At Risk of Poverty and Social Exclusion. (Eurostat, 2020, 4). Available online: https:/ / ec.europa.eu/eurostat/statistics-explained/index.php/Migrant_integration_statistics_-_at_risk_of_poverty_and_ social_exclusion (accessed on 10 October 2020).

35. EIB. Economics Department. Migration and the EU. Challenges, Opportunities, the Role of EIB. 2016. Available online: https:/ / www.eib.org/attachments/migration_and_the_eu_en.pdf (accessed on 4 January 2021).

36. Čuhlová, R.; Potužáková, Z. Highly qualified in the Czech Republic. J. Int. Stud. 2017, 10, 159-172. [CrossRef]

37. Gallardo, G.D.L.; Korneeva, E.; Strielkowski, W. Integration of migrants in the EU: Lessons and implications for the EU migration policies. J. Int. Stud. 2016, 9, 244-253. [CrossRef] [PubMed] 